\title{
VII. International Refugee Law and Judicial Dialogue from the Polish Perspective
}

Michał Kowalski*

\section{The Specificity of International Refugee Law and Judicial Dialogue}

International refugee law governs rules on granting protection to all human beings who were forced to leave their countries of origin because of the fear of persecution. As such it governs predominantly the States' obligations towards those in need and formulates human rights obligations. Yet, one should not overlook that the origins of international refugee law are of totally different character - they were shaped, starting from the beginning of the twentieth century, as legal instruments aimed at facilitating States to deal with migration flows. Indeed, migration flows, including these of mass character, are permanently present in international relations and may significantly disturb the functioning of particular States and the international society as a whole. Thus, the existence of a relevant international legal framework appeared to be a must

* Dr habil., Associate Professor, Faculty of Law and Administration, Jagiellonian University in Cracow, Poland. The author has been an adjudicating member of the Polish Refugee Board since 2009 and in this capacity has contributed to the development of the Board's case law, including some of the decisions referred to in the present text. All the case-law referred to as of 30 April 2016. 
- above all from the perspective of States' interests. It is only after World War II and in the context of the development of international human rights protection system that international refugee law turned to be human rights oriented. Nevertheless, States' interests left their unequivocal imprints on the modern international refugee law.

The turning point for the modern international law was the adoption in 1951 of the Geneva Convention relating to the Refugee Status (1951 Geneva Convention), ${ }^{1}$ which was subsequently amended by the 1967 New York Protocol. ${ }^{2}$ The 1951 Geneva Convention introduced in its famous Art. 1A the definition of the term 'refugee' and the 1967 New York Protocol lifted the relevant time and geographical limitations to the definition, ${ }^{3}$ which made it truly universal in its application. Since then the definition of the term 'refugee' has become widely accepted and introduced into national legal systems. Thus the $1951 \mathrm{Ge}$ neva Convention refugee definition forms nowadays the basis for legal frameworks of national refugee regulations as well as for regional refugee regulations such as the Common European Asylum System created within the European Union (EU).

Article 1A of the 1951 Geneva Convention states that the term 'refugee' should apply to any person who

owing to well-founded fear of being persecuted for reasons of race, religion, nationality, membership of a particular social group or political opinion, is outside the country of his nationality and is unable or, owing to such fear, is unwilling to avail himself of the protection of that country; or who, not having a nationality and being outside the country of his former habitual residence as a result of such events, is unable or, owing to such fear, is unwilling to return to it.

Thus, it is crystal clear from the very wording of the definition that it is open to interpretations that may vary. Indeed, the adopted understandings of the term persecution or of each of the five persecution grounds alter the scope of the definition. The same applies to other aspects of the definition and its application, especially as the 1951 Geneva Convention and the 1967 New York Protocol are silent on conditions for the refugee status determination procedure and in fact do not state any clear legal obligation to grant refugee status. Instead, the prohibition of refoulment

1 Convention Relating to the Status of Refugees (adopted 28 July 1951, entered into force 22 April 1954) 189 UNTS 137 (1951 Geneva Convention). As for 16 February 2016 there were 145 States-parties to the 1951 Geneva Convention.

2 Protocol Relating to the Status of Refugees (adopted 31 January 1967, entered into force 4 October 1967) 606 UNTS 267 (New York Protocol). As for 16 February 2016 there were 146 States-parties to the 1967 New York Protocol.

3 Note, however, that the geographical limitations existing prior to the adoption of the 1967 New York Protocol may apply further with the significant example of Turkey, which applies the refugee definition to persons coming from Europe only. 
was foreseen in Art. 33(1) of the 1951 Geneva Convention, which provides for the prohibition of expulsion or return of a refugee "to the frontiers of territories where his life or freedom would be threatened on account of his race, religion, nationality, membership of a particular social group or political opinion." Thus, the international legal framework of refugee protection remains within the significantly discretional right to grant asylum from persecution and the obligation to refrain from refoulement. Concepts such as the internal protection (flight) alternative, the save third country or the first country of asylum are - in their legal ambiguity - telling examples in this respect.

The above-mentioned characteristics of international refugee law should be analysed against the background of two important features. Firstly, there is no specific international court to apply international refugee law. Although the 1951 Geneva Convention provides in Art. 38 the judicial clause under which any dispute between the States-parties relating to its interpretation or application is to be referred to the International Court of Justice, this provision has never been so far applied. It is not surprising, as applying international refugee law is predominantly about granting or refusing protection to those in need and States persistently tended to secure their discretion in this respect. Yet, one has to remember about an enormously important role of the United Nations High Commissioner for Refugees (UNHCR), which was set up in 1950. Since then - and apart from offering factual protection to those replaced - the UNHCR has been shaping the international legal framework of refugee protection. It does so with a help of soft law measures, such as the Handbook on Procedures and Criteria for Determining Refugee Status under the 1951 Convention and the 1967 Protocol relating to the Status of Refugees ${ }^{4}$ as well as other UNHCR's numerous documents including guidelines and comments. Although non-binding, they significantly influence the States' practice and they remain the principal reference points on international refugee law.

The other aspect that should be mentioned is strictly linked with the first one, i.e. the crucial role of national determination authorities including national courts for the interpretation of international refugee law. Indeed, the national courts interpret and apply international refugee law and, in consequence, influence its development as they form States' treaty practice under the 1951 Geneva Convention and the 1967 New York Protocol. They may also contribute to the creation of parallel customary norms. This results in a tendency of national courts to refer to foreign courts' decisions. This kind of judicial dialogue (in its broadest understanding) is stimulated by the characteristics of the 1951 Geneva Convention as a treaty of a particular kind. A. Tzanakopoulos identifies three main characteristics that make "certain treaties particularly likely to become

4 UNHCR, 'Handbook on Procedures and Criteria for Determining Refugee Status under the 1951 Convention and the 1967 Protocol relating to the Status of Refugees' (Geneva 1992, reedited). 
the subject of judicial dialogue." 5 The first is the subject of the treaty as "the treaties dealing with issues that most States are likely to encounter in day-today domestic administration are of obvious importance to domestic courts: they are likely to be invoked in domestic court proceedings."' The 1951 Geneva Convention is explicitly mentioned by Tzanakopoulos in this context as 'the prime example. ${ }^{7}$ The other two characteristics identified are the discretional nature of a treaty and the multilateral character of a treaty. ${ }^{8}$ Indeed, given the previous observations, the 1951 Geneva Convention - although this time not labeled as such by Tzanakopoulos - may well aspire to the 'prime example' status also in these two regards.

National courts' refugee law references to the case law of foreign jurisdictions seem to be more developed in the common law systems. ${ }^{9}$ Despite the common legal tradition that undoubtedly makes such references more natural, the language aspect seems to be a practical and a very helpful facilitator, as English is the common language of most common law systems. ${ }^{10}$ Obviously, national courts' references to the case law of foreign jurisdictions take place also in civil law systems with frequent references to common law jurisdictions. ${ }^{11}$ Again, the status of English as the modern lingua franca is not to be underestimated. It is especially so, as the UNHCR has been always involved in promoting interpretative 'good practices' of national courts by making them available in its publications. The process has been fundamentally facilitated since the beginning of the Internet era.

In Central and Eastern Europe (the CEE) international refugee law has become the issue only since the turn of the 1980s and the 1990s. It was then, i.e. after the end of the Cold War era and after the democratization of the region, that the 1951 Geneva Convention and the 1967 New York stopped to be perceived, as it previously used to be in the Soviet bloc, as instruments of the 'imperialistic West'. The CEE States consecutively acceded the 1951 Geneva Convention and the 1967

5 A. Tzanakopoulos, 'Judicial Dialogue as Means of Interpretation', [in:] H. Aust, G. Nolte (eds), The Interpretation of International Law by Domestic Courts: Uniformity, Diversity, Convergence (Oxford University Press 2016) 80.

6 Ibidem, p. 79.

7 Ibidem.

8 Ibidem, p. 80-82.

9 F. Cafaggi et al., Judicial Interactions Techniques - Their Potential and Use in European Fundamental Rights Adjudication (European University Institute 2014), p. 40.

10 Hélène Lambert points out that "the British courts (including the Scottish Court of Session) have often explicitly referred to common law jurisprudence in asylum cases, in particular to decisions from Canada, New Zealand, Australia and the USA when interpreting certain provisions of the Refugee Convention", H. Lambert, 'Transnational Judicial Dialogue, Harmonization and the Common European Asylum System' (2009) 58 International and Comparative Law Quarterly 529 with references.

11 See e.g.: E. Benvenisti, 'Reclaiming Democracy: The Strategic Uses of Foreign and International Law by National Courts' (2008) 102 American Journal of International Law, p. 262 with references. 
New York Protocol ${ }^{12}$ and introduced the refugee definition to their national legislations. The process was gradual. In Poland, for instance, the first comprehensive legislative regulation on granting international protection to foreigners was adopted in 1997 only. The process could be slow as the CEE States were definitely not the major destination countries for asylum-seekers at that time. Also, the UNHCR played an active role in supporting the CEE States in creation of national legislative and institutional refugee legal framework. In the context of professional training offered by the UNHCR, references to the case law of foreign jurisdictions regarding the interpretation of the refugee definition or the application of the non-refoulement principle were self-evident. Again, the fact that the most accessible and illustrative materials were available in English played an important role in the process.

Nevertheless, two additional aspects gradually grew to influence the development of national refugee laws in the CEE States. The first was the increasing role of the European Court of Human Rights (the ECtHR), which since the late 1990s and the early 2000s has been perceived as the de facto asylum court. The other aspect was the accession process to the EU, which coincided with the intensive development of the EU migration and asylum policy. Both aspects were so comprehensive and of such significance that it seems justifiable to speak of the Europeanization of international refugee law.

\section{The Europeanization of International Refugee Law and Judicial Dialogue}

According to some doctrinal opinions, until the mid-eighties of the twentieth century, i.e. until the Member States of the then European Communities took the first inter-governmental actions aimed at forming common migration and asylum policies, the European asylum policy had not existed at all. ${ }^{13}$ Such an approach seems to underestimate the earlier activities of the Council of Europe, which had been persistently promoting liberal standards of refugee protection with both legally binding and non-binding measures. One must admit, nevertheless, that the actual influence of these strivings was rather limited. The role of the Council of Europe in shaping the European standards of refugee protection

12 The 1951 Geneva Convention and the 1967 New York Protocol were simultaneously acceded by, e.g., Hungary on 14 March 1989; Poland on 27 September 1991; then Czechoslovakia on 26 November 1991 (after the dissolution of Czechoslovakia the Czech Republic and Slovakia became States-parties to the Convention and the Protocol on 11 May 1993 and 4 February 1993, respectively). The Baltic States acceded the Convention and the Protocol in 1997 only (Estonia on 10 April 1997, Lithuania on 28 April 1997 and Latvia on 31 July 1997).

13 D. Joly, Heaven or Hell?: Asylum Policies and Refugees in Europe (Macmillan Press 1996), p. 44. 
has further diminished since the inception and subsequent evolution of the EU migration and asylum policies. This is no doubt correct, save for one important exception, i.e. the European Convention on Human Rights (the ECHR) and the related jurisprudence of the Strasbourg court.

It must be emphasized that neither the ECHR, nor its additional protocols provide for the right to asylum. However, it cannot be contested that human rights protection standards developed under the ECHR by the ECtHR apply also to asylum-seekers within the jurisdiction of the States-parties and form relevant and effective guarantees. The respective case law of the ECtHR has been developing since the 1990s. Article $3 \mathrm{ECHR}$ is definitely of the greatest importance in this respect. Its interpretation (intensively developed by the ECtHR since the famous 1989 Soering case $\left.{ }^{14}\right)$ introducing the prohibition of extradition, expulsion or return that might result in torture, inhuman or degrading treatment or punishment established the standard of protection reaching far beyond the non-refoulment principle, as provided for in Art. 33 of the 1951 Geneva Convention. The standard developed under Art. $3 \mathrm{ECHR}$ as well as other international human rights guarantees prohibiting torture contributed to the development of the non-refoulment principle as a customary international norm which - as may be claimed - has nowadays a significantly wider scope than its treaty equivalent encompassed in the 1951 Geneva Convention and, as such, may be attributed the peremptory character. ${ }^{15}$

The protection guaranteed to asylum-seekers under Art. 3 ECHR illustrated very well that the limitation of the 1951 Geneva Convention personal scope of application excluding individuals who, though not falling within the definition of a 'refugee' were in a real need of international protection. The ECHR guarantees contributed indirectly to the establishment of the new forms of international protection: the subsidiary protection and the temporary protection. Additionally, the protection of asylum-seekers granted under Art. 3 ECHR influenced the European States' interpretation of the notion of refugee as provided for in Art. 1A of the 1951 Geneva Convention. It is clearly visible, for instance, in cases where the persecution is suffered from the hands of nonState actors.

The guarantees granted under Art. 3 ECHR must be also taken into account as far as the mechanisms of determining the State responsible for examining the applications for asylum lodged in one of the EU Member States. The ECtHR claimed so already in the 2000 T.I. decision ${ }^{16}$ in relation to the United Kingdom obligations under Art. 3 ECHR in connection with its obligations under the 1990 Dublin

14 Soering $v$ the UK, App. no. 14038/88 (ECtHR, 7 July 1989).

15 G.S. Goodwin-Gill, J. McAdam, The Refugee in International Law (3 $3^{\text {rd }}$ ed., Oxford University Press 2007), p. 201 and 345.

16 T.I. v the UK, App. no. 43844/98 (ECtHR, inadmissibility decision, 7 March 2000). 
Convention. ${ }^{17}$ The relevant case law has been subsequently evolving in relation to the EU Dublin II Regulation with the significant examples of the well-known cases of M.S.S. ${ }^{18}$ and Tarakhel. ${ }^{19}$

Moreover, the obligations of the ECHR States-parties towards asylum-seekers must be also taken into account in the context of procedural guarantees directly or indirectly linked with the asylum procedure. It is so in relation to the asylum-seekers detention standards (Art. 5 ECHR), as well as in relation to the right to effective remedy in the cases of: firstly, potential expulsion or return that might result in violation of Art. 3 ECHR (Art. 13 in conjunction with Art. 3 ECHR); secondly, denial of family reunification (Art. 13 in conjunction with Art. 8 ECHR); and thirdly, decision on detention (Art. 5.4 ECHR). What is more, Art. 3 ECHR may also apply to the conditions of the asylum-seeker detention.

Thus, although the ECtHR does not interpret neither the 1951 Refugee Convention, nor the 1967 New York Protocol, the significance of the ECHR for asylum-seekers' protection remains obvious. One can even refer to the doctrinal opinion that under the ECHR - and especially under its Art. 3 - it is justifiable to speak of the implied right to de facto asylum. ${ }^{20}$ Interesting enough, the opinion submitted already in 1990, i.e. at the time when the asylum case law of the ECtHR was yet in statu nascendi. However, from the present day perspective it is obvious that the modern European asylum legal framework has been decisively shaped in the context of measures developed by the EU Member States.

The standards developed by the EU Member States regionally complement regulations of the universal international refugee law based on the 1951 Geneva Convention and the 1967 New York Protocol. The Common European Asylum System (the CEAS), established within the EU and consisting of a set of asylum directives and regulations, is explicitly based - as provided in the primary EU $\operatorname{law}^{21}$ - on these international agreements as its cornerstones. Yet, the EU regional standards

17 Convention determining the State responsible for examining applications for asylum lodged in one of the Member States of the European Communities and measures for its implementation (the Dublin Convention) (1997) O.J. C 254/1. The 1990 Dublin Convention entered into force on 1 September 1997. After the communitarisation of the EU migration and asylum policies under the Amsterdam Treaty the Dublin II Regulation was adopted in 2003 (Council Regulation 343/2003/EC of 18 February 2003 establishing the criteria and mechanisms for determining the Member State responsible for examining an asylum application lodged in one of the Member States by a third-country national (2003) O.J. L 50/1) and was subsequently replaced by its recast version of 2013 known as Dublin III Regulation (Regulation 604/2013/ EU of the European Parliament and of the Council of 26 June 2013 establishing the criteria and mechanisms for determining the Member State responsible for examining an application for international protection lodged in one of the Member States by a third-country national or a stateless person (recast) (2013) O.J. L 180/31). M.S.S. v Belgium and Greece, App. no. 30696/09 (ECtHR, 21 January 2012).

19 Tarakhel v Switzerland, App. no. 29217/12 (ECtHR, 4 November 2012).

20 T. Einarsen, 'The European Convention on Human Rights and the Notion of an Implied Right to de facto Asylum' (1990) 2 International Journal of Refugee Law 361.

21 Art. 78.1 TFEU and Art. 18 CFR. 
are significantly innovative and as such they have been influencing - at least to some extent - the universal ones. It is so with, e.g., the criteria and mechanisms for determining a State responsible for examining an asylum application; the temporary protection regime; establishing the legal framework of the subsidiary (to the refugee status) protection; interpreting the refugee definition in the context of internal protection (flight) alternative, gender or sexual orientation related persecution. What is more, the CEAS legal measures have been placed under the jurisdiction of the Court of Justice of the EU (the CJEU; formerly the European Court of Justice) and since then its asylum case law has become significant and, at least to some extent, has contributed to the mentioned standards' development. The CJEU interprets the EU secondary asylum legislation and in consequence, as it is legally based on the 1951 Geneva Convention and the 1967 New York Protocol, it interprets the provisions of the latter instruments as well. ${ }^{22}$ Indeed, as Roland Bank puts it:

the supranational setting of the [EU] law provides a framework of law that is much more powerful than the usual interplay between international and national law. It directly impacts on the national asylum systems by establishing, interpreting and, to a certain extent, enforcing binding rules in the application of EU law by EU $[\mathrm{M}]$ ember $[\mathrm{S}]$ tates that would have to be measured by the 1951 [Geneva] Convention and its 1967 [New York] Protocol. ${ }^{23}$

In the view of the above, it is apparent that asylum cases that are to be adjudicated on national level in the EU Member States demand references to international, supranational and national legal sources that coincide and interact. Thus, the judicial dialogue on refugee law dialogue becomes even more important. What is more, the complex relation of EU law and the ECHR, as well as the relevant status of the latter under the former must also be taken into account. It is especially the case since the CJEU refers in its case law to legal issues covered also by the ECtHR case law and this results in the European judicial dialogue par excellence.

22 R. Bank, 'The Potential and Limitations of the Court of Justice of the European Union in Shaping International Refugee Law' (2015) 27 International Journal of Refugee Law 2220 . Roland Bank notes that in fact "[r]egarding the 1951 [Geneva] Convention, the CJEU is the first international court to pronounce itself on questions arising in its application" (ibidem, 241). Yet, the quoted author is rather critical of the CJEU's role in this respect so far (passim). 


\section{International Refugee Law and Judicial Dialogue, Conversation or Interaction?}

The understanding of judicial dialogue as adopted by the editors of this volume comprises every reference in a national court's decision either to a decision of another national court of foreign jurisdiction or to an international court's decision. It seems, however, that while dealing with international refugee law a broader perspective on judicial dialogue may be useful or even indispensable. At least, this seems to be the case in Europe in the context of the described Europeanization of international refugee law. The two regional international courts, i.e. the ECtHR and the CJEU, although not asylum courts per se, dominated, in fact, the interpretation and application of international refugee law in Europe. Consequently, they have formally or informally influenced national asylum courts' case laws. What is more, both European courts could not have escaped entering into a dialogue on asylum matters with each other. Therefore, as far as the European judicial dialogue in asylum matters is concerned, four possible scenarios can be distinguished:

1) a national court refers in its decision to a decision of an international court;

2) a national court refers in its decision to a decision of another national court of foreign jurisdiction;

3) an international court refers in its decision to a decision of a national court;

4) an international court refers in its decision to a decision of another international court.

In asylum cases all situations mentioned above may take place, yet with various intensity. Without entering into a detailed analysis at this stage, it seems appropriate to claim that in the European context the situations listed under points one and four should be frequent as they are legally indispensable, whereas the situations listed under points two and three seem to be possible, yet far less obvious, and as such rather rare. Indeed, the first listed situation will take place in the context of safeguarding the ECHR guarantees to asylum-seekers under the jurisdiction of the States-parties and, as far as the relevant EU Member States are concerned, in the context of the EU preliminary ruling procedure. The situation listed under point four will result, firstly, from the fact that both European courts are obliged to address the same or overlapping legal issues on asylum matters. Also, the ECHR status under EU law will be an additional factor in this respect. Indeed, the national asylum courts in the EU Member States may be placed in an uncomfortable position while confronted with not necessarily coherent pronouncements of the ECtHR and the CJEU. Examples will follow in the subsequent part of the present text. 
The second of the mentioned situation is possible, as national courts will apply the same international legal norms: first of all, the refugee definition under the 1951 Geneva Convention. Yet, the reference to the case law may concern many other legal issues (also under EU law as implemented by the EU Member States) as well as factual findings. A foreign court's decision, if appropriately current, may be a valuable source on a country of origin information. Lastly, the situation mentioned under point three above may also take place with the relevant procedures before the international courts. The attempt to establish the European consensus by the ECtHR as the ECHR interpretation method may serve as a good example.

Before entering into a contextualized analysis of the above mentioned scenarios one should note that they may significantly vary in their character, too. Therefore, a more differentiated approach to the character of relations among asylum courts may appear helpful. Indeed, "academics use different terms for referring to the different forms of exchanges that occur between judges and courts around the globe. The term 'dialogue' has so far been the most common term used by legal academia to refer to this phenomenon, in addition, terms such as 'transnational judicial dialogue', 'conversation', and 'judicial interaction' have also been employed." ${ }^{24}$ Vast literature has been devoted to the analysis and characterizations of these exchanges in different contexts. ${ }^{25}$ Risking generalization, one may state that judicial dialogue "entails an ongoing exchange of arguments in order to reach common understandings. Thus, dialogue requires some sort of reciprocity among the judicial actors involved and it develops on a case by case basis over time." ${ }^{26}$ The other categories are of broader character, consist of more actors involved and include more informal relations among courts. O. Frishman points to three main forms of courts' interactions: face-to-face interactions, IT-based communication and cross-citations. ${ }^{27}$ The latter is to be equated with the judicial dialogue in the sense referred to above: "a way for courts to exchange their understanding of the best legal solution to a certain problem.." ${ }^{28}$ However, one should not underestimate the two former ways of courts' interactions. They remain less formal, yet they may turn out to be very influential. International Refugee Law is a very illustrative example in this respect. The refugee judges networks and associations such as the influential International Association of Refugee Law Judges $^{29}$ provide - through conferences, workshops, trainings, projects etc. - for actual face-to-face contacts which may prove to be very helpful in achieving harmonized approaches to particular legal problems. Again, in the EU context pro-

24 F. Cafaggi et al. (n. 10), p. 38, references omitted.

25

26

27

28

29
See e.g.: ibidem, 38-40 with extensive doctrinal references.

Ibidem, p. 39, references omitted.

O. Frishman, 'Transnational Judicial Dialogue as an Organisation Field' (2013) 19 European Law Journal, p. 747.

Ibidem, p. 748.

Established in 1995 and consisting of regional Chapters. See the Association's Internet site at <www.iarlj.org> (access: 30 April 2016). 
fessional trainings for judges organized by the European Asylum Support Office within its Judges' Network fulfill a similar function. Obviously, this kind of interaction is strictly linked to an IT-based communication. In addition, professional asylum resources offered by different entities and accessible online are of high importance. The UNHCR remains the most influential actor in this respect with its 'refworld' asylum resources portal. ${ }^{30}$

\section{The Judicial Dialogue on Refugee Law in the Polish Context}

\subsection{Introductory Remarks}

In the following section the contextualised instances of a judicial dialogue in the Polish practice of granting international protection to foreigners will be analysed. Of prime importance is the refugee status determination procedure that is initiated by an application for international protection and which, under the national law, consists of the determination of grounds for granting refugee status as well as of grounds for subsidiary protection. ${ }^{31}$ The Head of the Office for Foreigners (Szef Urzędu do Spraw Cudzoziemców) as the first instance and the Refugee Board (Rada do Spraw Uchodźców) as the appeal instance are the competent authorities in this context. A Refugee Board decision may be appealed to an administrative court. The judicial administrative procedure consists of two instances. The first instance is the Warsaw Administrative Court (Wojewódzki Sąd Administracyjny $w$ Warszawie) and its judgements may be appealed (a cassation appeal) to the Supreme Administrative Court (Naczelny Sad Administracyjny). The present analysis will focus on the case law of the Polish administrative courts. Nevertheless, the case law of the Refugee Board will be taken into account, too. The Refugee

30 See at: Refworld database <www.refworld.org> (access: 30 April 2016).

31 The procedure obliging a foreigner to return (the return procedure) bears separate characteristics and is now regulated under the Foreigners' Act of 12 December 2013. Within the return procedure two other forms of protection may be granted to a foreigner, i.e. the permit to remain for humanitarian reasons (the humanitarian permit) and the permit for tolerated stay (the tolerated stay permit). One of the premises to grant the humanitarian permit is the right to respect for private and family life within the meaning of Art. 8 ECHR. Until 1 May 2014 this aspect was taken into account within the refugee status determination procedure under the premises for granting the then tolerated stay permit (at that time the tolerated stay permit was the third form of granting protection to foreigners, if refugee status and subsidiary protection were refused and granting the then tolerated stay permit excluded expulsion decision). 
Board is a twelve-member body divided into four adjudicating panels (some decisions may be taken also by a single member of the Refugee Board). The members of the Refugee Board are independent and bound by the law only. Yet, the quasi-judicial character of the Refugee Board may be challenged as the Refugee Board does not settle a dispute between the parties but reconsiders an administrative case instead. Thus the Refugee Board does not exercise a purely judicial function. It is not clear whether the Refugee Board is covered by the concept of 'a court or a tribunal' under EU law. The Refugee Board has not tried to submit a reference for a preliminary ruling to the CJEU so far. Regardless of this fact, it may be noted that no Polish administrative court submitted a reference for a preliminary ruling referring on refugee law issue so far either.

The analysis will focus on relations between the courts that were listed in section 3 above under points one and two, i.e. in situations in which a national court refers in its decision to a decision of an international court or to a decision of another national court of foreign jurisdiction. The judicial dialogue between international courts and its significance for a national judge (adjudicator) will be also taken into account.

The analysis is divided into four subsections. Firstly, the general characteristics of the analysed references making up the refugee law judicial dialogue will be presented (4.2). Subsequently, the three selected particular issues will be analysed: the question regarding the understanding of the social group concept under the refugee definition (4.3); the application of the internal protection (flight) alternative principle (4.4); and the question of denial of access to adequate medical treatment in a country of origin as a ground for granting subsidiary protection (4.5).

\subsection{The General Characteristics of the Polish Contribution to the Judicial Dialogue on Refugee Law}

The conducted case law analysis shows that references to decisions of international courts and of national courts of foreign jurisdictions are not at all frequent. It is so especially in the second case. This flows from the fact that accessibility of such decisions is highly limited. The other major obstacle is the specificity of national regulations of, both, substantive and procedural nature.

In this context it is not surprising that the rare, identified examples of references to national courts' decisions do not regard legal questions but factual determinations of situations in the country of origin concerned. An illustrative example of such a reference is the decision of the Refugee Board ${ }^{32}$ in which the reference is made to the New Zealand Refugee Status Appeals Authority's decision ${ }^{33}$ in order to invoke the same assessment that Sikhs who live in India outside the Pun-

32 Case RdU-93-1/S/14 (Refugee Board, 29 May 2014). All the Refugee Board decisions referred to in the present text are unpublished and on file with the author.

33 Refugee Appeal 76456 (New Zealand: Refugee Status Appeals Authority, 15 March 2010). 
jab territory enjoy the same social and economic rights as other Indian nationals and that discrimination they might experience in this respect cannot be classified as persecution.

Of similar character was the reference in the 2003 Supreme Administrative Court judgement. ${ }^{34}$ The case concerned an applicant from Nigeria, who left the country of origin due to the declared threat from the Ogboni society. In his appeal to the Supreme Administrative Court the applicant referred to national decisions from Australia and Canada in which cases based on the same facts were adjudicated positively for the applicants. In its judgement the Supreme Administrative Court quashed the appealed decision of the Refugee Board (the judgement was delivered in the framework of the single judicial administrative procedure binding at that time) because of deficiencies in evidentiary procedure and stated that the circumstances regarding the threat from the Ogboni society in Nigeria must be clarified in more detail. Yet, the Supreme Administrative Court made a reference to the UK court's judgement in which it considered the threat from the Ogboni society in Nigeria and decided the case negatively for the applicant. ${ }^{35}$

Another brief reference to the UK court's decision was identified in the 2015 Administrative Court's judgement. ${ }^{36}$ The Court approvingly referred to the Refugee Board's findings on the identification of the groups in high risk of persecution in Iran, which were based on the expert opinions and the identical findings in the UK court judgment. ${ }^{37}$

It is characteristic for all of the above examples that references were made to the decisions of courts from English speaking States only. They were all written in English and made accessible online in the open access refugee law databases. It is also characteristic that all references were of very laconic and general character.

The references to a foreign national court's decision regarding legal questions are even less frequent. In fact, only one such decision has been identified. This is the 2008 Supreme Administrative Court judgement. ${ }^{38}$ There the Supreme Administrative Court referred to the interpretation of the concept of a social group as a reason for persecution on gender grounds within the definition of a refugee

34 Case V SA 1494/02 (Supreme Administrative Court, 29 January 2003). All the Supreme Administrative Court and the Regional Administrative Courts judgements referred to in the present text are available via Centralna Baza Orzeczeń Sądów Administracyjnych (Central Administrative Courts' Decisions Database) at <http://orzeczenia.nsa.gov.pl/cbo/query> (access: 30 April 2016).

Omoruyi v Secretary of State for the Home Department Imm AR 175 (Appellate Court Civil Division, 2001) available via The University of Michigan Law School, Refugee Case Law, $<$ www.refugeecaselaw.org> (access: 30 April 2016).

37 S.B. Iran v Secretary of State for the Home Department (no source reference included in the Warsaw Administrative Court's judgement).

38 Case II OSK 237/07 (Supreme Administrative Court, 8 May 2008). 
under Art. 1A of the 1951 Refugee Convention. Such concept of a social group was used in national decisions in Canada, the US and the UK. The Supreme Administrative Court judgement will be analysed in more detail in subsection 4.3 below.

The Polish administrative courts' and the Refugee Board's references to the ECtHR and CJEU case law on refugee law are definitely more frequent. For the ECtHR case law, this was particularly frequent before the 1 May 2014 major amendment of 2003 Act on granting protection to foreigners on the territory of the Republic of Poland. Before that amendment the refugee status determination procedure covered also the phase of determination of grounds for the tolerated stay permit, i.e. the auxiliary form of protection granted to foreigners in Poland. The statutory grounds for the tolerated stay permit included, among others, violations of selected guarantees of the ECHR as far as they excluded expulsion of a foreigner. Thus, references to law of the ECHR as established in the case law of the ECHR determining the scope of the particular ECHR standards were, in fact, of mandatory character. The references were made mainly to decisions against other States-parties to the ECHR as there were no Polish cases concerning expulsions in such context. Particularly frequent were references to standards established by the ECtHR under Art. 8 ECHR, which excluded expulsion on the basis of the right to respect for family life. Numerous decisions of the Refugee Board may be identified in which the relevant standard was reconstructed in detail and the application structure of Art. 8 ECHR was used. ${ }^{39}$ Yet, the case law of the Refugee Board was diversified and one could also point to many decisions in which the relevant considerations on the right to respect for family life were not adequate or even fake. In the latter case the references to the old cases were made via published compilations of the ECtHR case law extracts. Also, the case law of the Polish administrative courts in the present context is quite broad and includes examples of references to the case law of the ECtHR and the CJEU. ${ }^{40}$

As far as the tolerated stay permit is concerned, one decision of the Refugee Board is particularly worth mentioning. This is the 2009 decision on granting the tolerated stay permit to a Chechen fighter. ${ }^{41}$ The decision includes extensive references to the ECtHR case law on Art. 3 ECHR. The Refugee Board firstly referred to numerous judgements of the ECtHR against Russia in order to demonstrate that the standard of Art. 3 ECHR had been in Russia consistently and widely violated in many its aspects. Subsequently the Refugee Board stated that

according to the well-established case law of the ECtHR (starting with the judgements in cases of Soering $v$ the United Kingdom of 7 July 1989, application no. 14038/88; A 161;

39 See e.g. Refugee Board cases: RdU-1182-1/S/09 (14 January 2010); RdU-161-1/S/12 (28 May 2012); RdU-72-5/S/08 (14 October 2013).

40 See e.g.: case IV SA/Wa 1387/13 (Warsaw DAC, 15 October 2013).

41 Case RdU-129-4/S/07 (Refugee Board, 3 April 2009). 
the judgement regarded surrendering of a foreign national for extradition; and Cruz Veras and others $v$ Sweden of 20 March 1991, application no. 15576/89; A 201; the judgement regarded expulsion of a foreign national) both surrendering and expulsion of a foreign national that would put him or her at risk of treatment prohibited under Art. 3 ECHR results in its violation. Thus, the guarantees of Art. 3 ECHR imply the prohibition of surrendering as well as of expelling a foreign national to the State in which he or she would be at risk of prohibited treatment. The absolute and non-derogable character of the protection under Art. 3 ECHR implies further that the guarantees resulting from it must not be excluded in any circumstances and notwithstanding any threat from the individual concerned which has been recently confirmed by the ECtHR in the judgement in case of Saadi $v$ Italy of 28 February 2008 (application no. 37201/06; see especially para. 124-149 with references to earlier case law of the ECtHR). ${ }^{42}$

The references to the extradition under the ECtHR case law were apparently made because of independent extradition proceedings, which were then pending simultaneously. The references to the ECtHR case law were of crucial importance as it was established that the applicant was at risk of serious violation of human rights in the country of origin, including the risk of torture. Granting of the refugee status was excluded, as was granting subsidiary protection, because the applicant was sentenced for criminal offence already while in Poland and the relevant security authorities issued a document stating that the applicant was a threat to the public security and order. Yet, the latter was not the premise for refusal to grant the tolerated stay permit. The then binding law was, however, not fully coherent and the threat to the public security and order constituted a premise for withdrawal of the permit. Nevertheless, the Refugee Board granted the tolerated stay permit to the applicant and underlined that absolute character of the protection resulting from Art. 3 ECHR and stated that:

according to the principle of subsidiarity being the basis of the ECHR (Art. 1) it is the national authorities of the States-parties to the ECHR that are predominantly responsible for safeguarding the conventional guarantees. The ECHR forms part of the domestic legal order

42 "Zgodnie z ustalonym orzecznictwem ETrPC (począwszy od wyroków w sprawach Soering przeciwko Zjednoczonemu Królestwu z dnia 7 lipca 1989 r., skarga nr 14038/88; A 161; wyrok dotyczył sytuacji przekazania cudzoziemca w trybie ekstradycji; i Cruz Veras i inni przeciwko Szwecji z dnia 20 marca 1991 r. (skarga nr 15576/89; A 201; wyrok dotyczył sytuacji wydalenia cudzoziemca) tak przekazanie, jak i wydalenie cudzoziemca, które skutkowałoby narażeniem go na traktowanie zabronione w art. 3 EKPC, prowadzi do jego naruszenia. Gwarancje art. 3 EKPC implikują więc zakaz tak przekazania, jak i wydalenia cudzoziemca do państwa, w którym byłby narażony na zabronione traktowanie. Absolutny i niederogowalny charakter ochrony na podstawie art. 3 EKPC implikuje też, że wynikające z niego gwarancje nie mogą zostać wyłączone w żadnych okolicznościach i niezależnie od zagrożenia, które jednostka może stanowić, co w ostatnim czasie zostało potwierdzone przez ETrPC w wyroku w sprawie Saadi przeciwko Włochom z dnia 28 lutego 2008 r. (skarga 37201/06; zob. zwłaszcza par. 124-149 i tam cytowane wcześniejsze orzecznictwo ETrPC)", ibidem. 
and may be applied directly and according to Art. 91 with conjunction with Art. 241.1 of the Constitution of the Republic of Poland of 1997 [references omitted] has precedence over a regular law if provisions of the latter cannot be reconciled with the ECHR. ${ }^{43}$

The Warsaw Regional Prosecutor appealed the Refugee Board decision, which constituted the only case of such appeal since the establishment of the Refugee Board in 1999. The Warsaw Administrative Court in its judgment of 4 December 2009 dismissed the appeal and fully shared the argumentation of the Refugee Board's reasoning. ${ }^{44}$

As far as grounds for granting refugee status as well as for granting subsidiary protection are concerned, the references to the case law of the ECtHR appear in contexts, which will be subject to a separate analysis in subsections $4.3-4.2$ below.

As mentioned above, so far no Polish administrative court has referred a question regarding refugee law issues to the CJEU. Nevertheless, the significance of the CJEU case law for the interpretation of the EU asylum acquis has been, as indicated in section 2, consistently increasing in the recent years. Thus, the interpretative positions of the CJEU must be taken into account also by Polish courts, which is the case in practice. Yet, the direct references to particular judgements of the CJEU are made both in the case law of administrative courts and that of the Refugee Board albeit they are not frequent. They appear, for instance, in cases in which an applicant (especially if provided with legal aid) refers to a particular judgement within the framework of the procedure. ${ }^{45}$ More importantly, direct references also appear if the interpretative position of the CJEU determines particular decision of a case. It is so, e.g., in cases dealing with the refusal to perform military service in an armed conflict as a reason for persecution. In some cases the Refugee Board referred directly to the interpretative standard as established

43 "W myśl leżącej u podstaw EKPC zasady subsydiarności (art. 1 EKPC) to na organach krajowych państw stron EKPC ciąży podstawowy obowiązek zapewnienia przestrzegania gwarancji konwencyjnych. EKPC stanowi część krajowego porządku prawnego i jest stosowana bezpośrednio, a zgodnie z art. 91 w związku z art. 241 ust. 1 Konstytucji Rzeczpospolitej Polskiej z 1997 r. (Dz. U. 97.78 .483 z późn. zm.) ma pierwszeństwo przed ustawą jeżeli ustawy nie da się pogodzić z EKPC", ibidem.

44 Case V SA/Wa 874/10 (Warsaw Administrative Court, 4 December 2009). Also the extradition proceedings ended up with a court's decision prohibiting the extradition. All that resulted in discontinuation of the proceedings before the ECtHR; Mamilov v Poland, App. no. 18358/07 (ECHR, inadmissibility decision/striking out of the list of cases, 20 October 2010).

45 See e.g.: case RdU-908-1/S/09 (Refugee Board, 23 October 2009). The Refugee Board pointed out that the representative of the applicant wrongly referred to the evidence standard as established by the CJEU in the Elgafaji judgement (Case C-465/07, Meki Elgafaji, Noor Elgafaji $v$ Staatssecretaris van Justitie, CJEU, 17 February 2009) because the case under consideration before the Refugee Board regarded the country of origin (Republic of Guinea) where neither international armed conflict nor non-international armed conflict within the meaning of Art. 15(c) of the 2004 Qualification Directive had been pending at the time. 
by the CJEU in Shepherd. ${ }^{46}$ Other examples are cases dealing with the question of denial of access to adequate medical treatment in the country of origin as a ground for granting subsidiary protection. In some cases the Refugee Board as well as a regional administrative court referred directly to the interpretative position of the CJEU in M'Bodj. ${ }^{47}$ The latter question will be dealt with more broadly in subsection 4.5 .

Other interesting examples are decisions of the Refugee Board regarding applicants seeking refugee status because of the danger of persecution based on sexual orientation. Indeed, asylum claims related to sexual orientation and gender identity have become broadly discussed in the recent years and resulted in a real European judicial dialogue between the $\mathrm{CJEU}^{48}$ and the $\mathrm{ECtHR}^{49}$ with some important contributions from national courts. ${ }^{50}$ There were also a few such cases decided by the Polish authorities, yet this happened before the delivery of the CJEU judgements. It is worth stressing that decisions of the Refugee Board appeared to be consistent with subsequent interpretative positions of the CJEU and to some extent they were even significantly more liberal. ${ }^{51}$ The Refugee Board stated, among others, that the very penalization of a homosexual act in a country of origin amounted to an act of persecution unless it may be demonstrated that a relevant law is not at all applied in practice. Also, the Refugee Board stated clearly that there are no objective methods allowing for definite medical assessment of one's sexual orientation and consequently they must not be applied in the refugee status determination procedure. According to the Refugee Board position, the sexual orientation should be determined upon an applicant's declaration, yet it requires verification of his

46 Case C-472/13, Andre Lawrence Shepherd v Bundesrepublik Deutschland (CJEU, 26 February 2015). See e.g.: the following decisions of the Refugee Board, which all regarded the Ukrainian applicants and all included identical references to paragraphs 47-56 of the Shepherd judgement: RdU-746-1/S/15 (3 September 2015); RdU-794-1/S/15 (3 September 2015); RdU-780-1/S/15 (30 September 2015); RdU-1050-1/S/15 (9 November 2015).

47 Case C-542/13, Mohamed M'Bodj v État belge (CJEU, 18 December 2014).

48 CJEU cases: C-199/12-C-201/127, X, Y and Z v Minister voor Immigratie en Asiel (7 November 2013); C-148/13-C-150/13, A, B, C v Staatssecretaris van Veiligheid en Justitie (2 December 2014).

49 Recent ECtHR cases: M.E. v Sweden, App. no. 713398/12 (Chamber, 26 June 2014), M.E. v Sweden, App. no. 713398/12 (Grand Chamber, 8 April 2015). See also ECtHR cases: F. $v$ the UK, App. no. 17341/03 (inadmissibility decision, 22 June 2004) and I.I.N. $v$ the Netherlands, App. no. 2035/04 (inadmissibility decision, 9 December 2004).

50 See: HJ (Iran) and HT (Cameroon) v Secretary of State for the Home Department (the United Kingdom Supreme Court, 7 July 2010), para. 82. For commentary see: J. Weßels, 'HJ (Iran) and HT (Cameroon) - Reflections on a new test for sexuality-based asylum claims in Britain' (2012) 24 International Journal of Refugee Law, p. 815.

51 For the extensive analysis see: M. Kowalski, 'Sexuelle Orientierung im Flüchtlingsrecht und im allgemeinen Migrationsrecht Polens unter besonderer Berücksichtigung der Verifizierungsproblematik im Verfahren', [in:] C.D. Classen, R D. ichter, B. Łukańko (eds), 'Sexuelle Orientierung' als Diskriminierungsgrund. Regelungsbedarf in Deutschland und Polen? (Mohr Siebeck 2016), p. 316. 
credibility in general. One of the Refugee Board decisions including the above mentioned positions was deemed by the UNHCR as an example of jurisprudential good practice, translated in extenso into English and made available in the refworld database. ${ }^{52}$

\title{
4.3. Defining the Concept of a 'Social Group'
}

The already mentioned 2008 Supreme Administrative Court judgement deserves particular attention here because of numerous references to a multitude of foreign judgments. It is a rare example of a Polish court referring to decisions of national courts of foreign jurisdictions as indicated above in section 3.2 of the present text. The Court adjudicated on the question of a membership in a particular social group as a reason of persecution due to gender within the context of Art. 1A of the 1951 Geneva Convention and it included references to the national decisions made in Canada, the US and the UK. The Supreme Administrative Court judgement is important indeed, as it is the first Polish decision declaring that women may constitute a particular social group within the meaning of the refugee. The Supreme Administrative Court quashed the appeal judgement of the DAC due to, among others, complete ignorance of this aspect in the judgement of the first instance and in the decisions of the Head of the Office for Foreigners and the Refugee Board.

The Supreme Administrative Court reconstructed the concept of a social group starting with the references to cases of national courts of foreign jurisdictions and only subsequently referred to the definition of, the then binding, 2004 Qualification Directive. The national cases referred to (nota bene without any source references) were the judgement of the Supreme Court of Canada of 5 March 1990 in Attorney General of Canada v P.F. Ward and the decision of the US Board of Immigration Appeals of 1 March 1985 in Acosta-Solorzano v INS - no doubt influenced the scope and the very wording of the definition of a social group as adopted in Art. 10(d) of the 2004 Qualification Directive. It reads:

\begin{abstract}
a group shall be considered to form a particular social group where in particular: - members of that group share an innate characteristic, or a common background that cannot be changed, or share a characteristic or belief that is so fundamental to identity or conscience that a person should not be forced to renounce it, and - that group has a distinct identity in the relevant country, because it is perceived as being different by the surrounding society.
\end{abstract}

Thus, it may be claimed that the references to national decisions made by the Supreme Administrative Court in this respect were only of ornamental character.

52 Case RdU-178-1/S/12 (Refugee Board, 25 July 2012) unofficial English translation by the UNHCR available at <http://www.refworld.org/docid/5037a3892.html> (access: 30 April 2016). 
References made by the Supreme Administrative Court that were definitely of greater importance regarded national decisions in which a particular social group was determined on gender grounds. It was so in the cited case concerning a 19-year-old Mexican woman who was the victim of domestic violence committed by her father. The Court determined in this case that family should be considered as a particular social group. ${ }^{53}$ In the case before the Supreme Administrative Court the appellant was the Russian national coming from Dagestan who claimed that she was a victim of domestic violence inflicted by her husband. Of crucial importance in this case was the reference to the well-known and widely commented decision of the UK House of Lords in Islam and Shah of 1999. ${ }^{54}$ The basis in the Islam and Shah case was, as the Supreme Administrative Court put it, "determination that a person concerned lived in a society stigmatizing women who were perceived as behaving against social and cultural norms being binding and widely accepted in that society." ${ }^{55}$ It was suggested in the Islam and Shah case, though not directly concerning the analysis of the Supreme Administrative Court, that alternatively to the determination of recognising all women in Pakistan as constituting a particular social group, it was possible to adopt additional criteria allowing for narrower definition of a particular social group consisting of women sharing also other common characteristics such as "Pakistani women accused of transgressing social mores and who are unprotected by their husbands or other male relatives." The Supreme Administrative Court's position may be perceived as in favour of such approach aimed at recognizing certain narrower groups of women in a particular society as a social group within the context of the refugee definition. Yet, the Supreme Administrative Court has not elaborated on this issue explicitly and the issue still remains debatable in the recent case law. ${ }^{56}$

Nevertheless, the Supreme Administrative Court explicitly stated that in case of danger of persecution from non-State actors

the condition of the absence of State's protection must not be understood in every case as an unconditioned obligation of personal exhausting of the relevant domestic procedures. The fact that the appellant has not referred herself to the state authorities for protection does

53 Aguirre Cervantes v INS (21 March 2001) as accessed via (2001) 13 International Journal of Refugee Law 586.

54 Islam $v$ Secretary of State for the Home department; R. V. Immigration Appeal Tribunal, exp. Shah (1999) 2 AC 629 (HL).

55 "Stanowiło ustalenie, że strona żyła w społeczeństwie piętnującym kobiety postrzegane jako postępujące w sposób niezgodny ze społecznymi i kulturalnymi normami obowiązującymi i powszechnie akceptowanymi w tym społeczeństwie", case II OSK 237/07 (Supreme Administrative Court, 8 May 2008).

56 See especially: case RdU-705-2/S/15 (Refugee Board, 27 April 2016) including the separate opinion. 
not have the decisive significance for the dismissal of the refugee status request. Important is determining whether the appellant would have obtained protection if she had requested for it. ${ }^{57}$

This position has been strengthened by the reference to the Isalm and Shah judgment where the UK House of Lords determined that in Pakistan women's charges against their husbands are not only ineffective but may also result in increased danger of them being mistreated.

The analysed Supreme Administrative Court judgement is an illustrative example of an interpretation of international law by a national court. By referring to other national decisions in the form of cross-citations (in the Islam and Shah the UK House of Lords referred to other national cases which were referred by the Supreme Administrative Court as well) national courts pursue judicial dialogue par excellence (proper judicial dialogue). The Supreme Administrative Court contributed to that dialogue engaging in the discussion with the pronouncements of the UK House of Lords. Regrettably, the research carried out in preparation of the present paper shows that this is an isolated example. Again, one should remark that all references mentioned are to decisions of courts from English speaking States, which are available in open access refugee law databases.

Moreover, it should be remarked that the commented Supreme Administrative Court judgement's influence on the case law of the Polish refugee status determination authorities and administrative courts was rather modest. The cases regarding, widely understood, domestic violence against women are decided positively for applicants, only if they are found credible. This is a very challenging threshold for this kind of cases and the evaluation is carried out not with the view to grant refugee status but rather subsidiary protection because of serious harm consisting of torture or degrading or inhuman treatment (previously also with the view to grant a tolerated stay permit for the same reasons).

The acceptance for recognizing women as constituting a particular social group in a certain country of origin is itself not questioned and that especially in the light of the last sentence of Art. 10(d) of the 2011 Qualification Directive. ${ }^{58}$ Yet, in the present Polish case law it seems to be understood as limited

57 "Warunek braku ochrony ze strony państwa nie może być w każdym przypadku rozumiany jako bezwzględny obowiązek wyczerpania dostępnych w kraju procedur ochronnych osobiście. Okoliczność, że skarżąca nie zwróciła się do organów państwa o pomoc nie może mieć decydującego znaczenia dla uzasadnienia odmowy nadania statusu uchodźcy. Istotne jest ustalenie, czy skarżąca otrzymałaby pomoc państwa, gdyby się o nią zwróciła", case II OSK 237/07 (Supreme Administrative Court, 8 May 2008).

58 "Gender related aspects, including gender identity, shall be given due consideration for the purposes of determining membership of a particular social group or identifying a characteristic of such a group." See also Art. 60 of the 2011 Council of Europe Convention on preventing and combating violence against women and domestic violence, CETS No. 210. 
to situations in which it is possible to determine that in a particular country of origin every woman is at risk of persecution because of being a woman only. Indeed, this is very restrictive standard as such situations will be very rare in practice.

In the context analysed, one may illustratively point out the 2014 Warsaw Administrative Court judgement ${ }^{59}$ regarding the case of a Chechen woman claiming that because of the social situation in Chechnya, her social status as a single mother with a minor child places her within a social group of women in the same situation. The Court did not share this line of argumentation and limited itself to the statement that being a single mother is not sufficient, as the claimant had not proved her membership to an organised group of single mothers in the country of origin. Conditioning the recognition for a particular social group on "membership in an organised group of women" proves a deep misunderstanding of the concept. The Warsaw Administrative Court's judgement lacks not only references to any foreign case law but also to the Supreme Administrative Court judgement of 2008. The case law of the Refugee Board is not harmonious, either. Indeed, in this kind of cases the judicial dialogue would undoubtedly contribute to a more uniform and foreseeable application of the binding law.

\subsection{Applying the Internal Protection (Flight) Alternative Principle ('the IPA principle')}

Another significant example of judicial dialogue in the context of refugee law is applying the internal protection (flight) alternative (IPA) principle. This is a very important and current issue in the Polish practice of dealing with asylum applications lodged by Ukrainians from Crimea under Russian occupation and from the Donetsk and Luhansk regions. Decisions taken by the Polish authorities in such cases are in vast majority negative exactly due to the application of the IPA principle. Thus, it is a decisive aspect of such cases.

The IPA was foreseen neither in the 1951 Geneva Convention nor in the 1967 New York protocol, yet, it forms nowadays the unquestionable part of refugee law. ${ }^{60}$ Beyond the international refugee law the same mechanism is applied in the

59 Case IV SA/Wa 1557/14 (Warsaw Administrative Court, 29 October 2014).

60 As it is stated in para. 91 of the UNHCR Handbook: "The fear of being persecuted need not always extend to the whole territory of the refugee's country of nationality. Thus in ethnic clashes or in cases of grave disturbances involving civil war conditions, persecution of a specific ethnic or national group may occur in only one part of the country. In such situations, a person will not be excluded from refugee status merely because he could have sought refuge in another part of the same country, if under all the circumstances it would not have been reasonable to expect him to do so." See also: UNHCR, Guidelines on International Protection No. 4: "Internal Flight or Relocation Alternative" within the Context of Article 1A(2) of the 1951 Convention and/or 1967 Protocol Relating to the Status of Refugees (23 July 2003) 
general human rights law. For instance, the ECtHR routinely engages the IPA principle to adjudicate on cases regarding expulsion or other legal or factual forms of transfer of a foreigner to a third State where the foreigner's rights would be endangered on the part of the territory only. ${ }^{61}$ Indeed, it was the case law of the ECtHR that has significantly contributed to the reliance on the internal relocation of persons in search of protection also in refugee law context, the CEAS including. The IPA was directly foreseen in Art. 8 of the Qualification Directive of 2004, which was subsequently slightly modified in its recast version of 2011. It is explicitly transposed into Polish law in Art. 18 of the 2003 Act on granting protection to foreigners. Yet, one should remember that under Art. 8 of the Qualification Directive the IPA may be applied but the Member States may choose to apply more favourable standards of treatment.

While applying the IPA at least four basic factors must be taken into account. ${ }^{62}$ Firstly, before the IPA is applied, it must be first determined that a person concerned would be at a risk of persecution or could suffer a serious harm on a part of a territory of a country of origin. Secondly, the IPA should not, in principle, be applied when the perpetrators are the authorities of the country of origin or they tolerate acts of persecution or serious harm. Thirdly, the safe parts of the country of origin should be identified as precisely as possible. Finally, the IPA application requires the establishment of criteria for assessing the situation in safe parts of a country of origin and for answering the question as to whether conditions there safeguard access to effective protection. These are the criteria mentioned in last sentence of Art. 8(1) of the Qualification Directive according to which a person concerned can "safely and legally travel to and gain admittance to that [safe] part of the country and can reasonably be expected to settle there." All that should be assessed, following Art. 8(2) of the Qualification Directive with "regard to the general circumstances prevailing in that part of the country and to the personal circumstances of the applicant."

As far as the assessment of Ukrainian applications by the Polish authorities is concerned, the first two factors mentioned above are not problematic. In principle, applicants from Crimea meet the criteria to be granted refugee status

$\mathrm{HCR} / \mathrm{GIP} / 03 / 04$; The Michigan Guidelines on the Internal Protection Alternative (11 April 1999) - Goodwin-Gill G.S., McAdam J. (n. 16) 123.

61 See: Chahal $v$ the UK, App. No. 22414/93 (ECtHR, 15 November 1996). As far as the more recent case law is concerned see e.g.: the illustrative cases referring to the changing situation in Somalia: Salah Sheekh v the Netherlands, App. no. 1948/04 (ECtHR, 11 January 2007), Sufi and Elmi $v$ the UK, App. nos 8319/07 and 11449/07 (ECtHR, 28 June 2011), K.A.B. v Sweden, App. no. 886/11 (ECtHR, 5 September 2013), R.H. v Sweden, App. no. 4601/14 (ECtHR, 10 September 2015).

62 For an extensive discussion, see: L. Aldenhoff, G. Clayton, P. McDonough, Actors of Protection and the Application of the Internal Protection Alternative. European Comparative Report (European Council on Refugees and Exiles, 2014), <http://www.ecre.org/component/downloads/ downloads/996.html> (access: 30 April 2016). Also: UNHCR, Guidelines on International Protection No. 4 ..., para. 7 . 
and applicants from the Donetsk and Luhansk regions meet the criteria to be granted subsidiary protection due to the situations in the parts of the country of origin they come from. Also, it is beyond doubts that the sources of persecution or serious harm are not the Ukrainian authorities but other entities, be that Russian authorities and/or non-State actors supported by the latter. Moreover, the Ukrainian authorities are unable to stop and prevent their activities. What remains challenging while applying the IPA to the Ukrainian applications are the two other factors and particularly the last of them - establishing the relevant criteria for assessment of actual accessibility of effective protection. ${ }^{63}$

Turning now to the question of judicial dialogue in the context of the IPA, it was already mentioned above that the IPA references to national decisions may regard assessment of factual situations in particular countries of origin, especially in their safe parts, and as such they have the character of the country of origin sources of information. It was exactly the case of the 2003 Supreme Administrative Court judgement and the 2014 Refugee Board decision, both referred to in the subsection 4.2 above. However, the Polish references to foreign national decisions with regard to the normative framework of the IPA have not been identified. ${ }^{64}$ Nevertheless, in the IPA cases, the Polish decisions include frequent references to the UNHCR's guidelines as well as sporadic ones to the ECtHR case law. The latter is the example of a reference of a national court to a decision of an international court as indicated above in point 1 of the subsection 3 of the present text.

The references to the ECtHR case law appeared in the cases in which the Refugee Board dealt with the appropriate standard of actual accessibility of effective protection. In one of such cases the decision of the Refugee Board was quashed by the Warsaw Administrative Court judgement due to the Refugee Board's inadequate evidentiary findings on actual accessibility of protection in the safe part of Ukraine including access to employment, social benefits, medical and psychological care, educational opportunities and permanent housing as basic and indispensible conditions safeguarding normal living. ${ }^{65}$ According to the Court, only

63 This subsection is based on: M. Kowalski, 'Konflikt na Ukrainie a praktyka udzielania ochrony cudzoziemcom na terytorium Rzeczpospolitej Polskiej' [Ukrainian Conflict and the Practice of Granting Protection to Foreigners on the Territory of the Republic of Poland], [in:] D. Pudzianowska (ed.), Status cudzoziemca w Polsce w świetle wspótczesnych wyzwań międzynarodowych [Foreigner's Status in Poland in Light of the Contemporary International Challenges] (Wolters Kluwer 2016), p. 96. See there for an extensive analysis.

64 Even though it is perfectly possible as shown by the 2008 Czech Supreme Administrative Court's judgement. When considering the standards of the IPA application, the Court referred to the UNHCR guidelines and one ECtHR judgement (Salah Sheekh $v$ the Netherlands). In addition, the Court also evoked the UK House of Lords judgement in Januzi, Hamid and others $v$ Secretary of State for the Home Department of 15 February 2006; Judgement of the Supreme Administrative Court of the Czech Republic (Nejvyšši správní soud) of 24 January 2008, E. M. $\checkmark$ Ministry of Interior, 4 Azs 99/2007-93. Extracts in English are available in refworld database. 
if the mentioned conditions are fulfilled the actual accessibility of effective protection is safeguarded. Yet, the Refugee Board disregarded the Court's position and appealed to the Supreme Administrative Court. ${ }^{66}$ In the reasoning supporting the appeal claim, the Refugee Board shared the Court approach that, while assessing whether an applicant can reasonably be expected to settle in the safe part of the country of origin, apart from personal safety considerations also considerations regarding the standard of living must be taken into account. Yet, the Refugee Board put into question the criteria the Warsaw Administrative Court applied for assessing whether expectations to settle in the safe part of the country of origin are reasonable. According to the Refugee Board position, the Court's approach was not to determine what would be the minimal standard allowing for a refugee to settle down, but what were the conditions for a general wellbeing of the person concerned.

The Refugee Board's arguments in the appeal claim were directly influenced by the ECtHR case law. The Refugee Board presented its detailed analysis of the 2011 ECtHR judgement in Sufi and Elmi in which the ECtHR stated, referring also to its previous case law, that "Article 3 [of the ECHR] does not preclude the Contracting States from placing reliance on the internal flight alternative provided that the returnee could travel to, gain admittance to and settle in the area in question without being exposed to a real risk of Article 3 ill-treatment" ${ }^{67}$ and that such ill-treatment may in exceptional cases result also from socio-economic and humanitarian conditions, if grounds against removal are 'compelling'. The Refugee Board referred to the ECtHR position as far as it conditioned the applicability of the IPA on determinations made with the help of the test established in the N. $v$ the UK (compelling humanitarian grounds ${ }^{68}$ ) or of the test established in the M.S.S. $v$ Belgium and Greece (official indifference in a situation of serious deprivation or want incompatible with human dignity ${ }^{69}$ ). It must be noted that the choice of the relevant test was dependant on the sources of the insufficient humanitarian situation. The Refugee Board quoted the ECtHR position that the $N$. case test was appropriate if extremely dire humanitarian conditions resulted exclusively or mainly from poverty or lack of resources following a naturally occurring phenomenon, such as a drought. Yet, in circumstances in which dire humanitarian conditions emanate not only from poverty and naturally occurring phenomena but also from direct and indirect actions of the parties of the conflict (as it was the case in Somalia and evaluated in in Sufi and Elmi), the ECtHR accepted the M.S.S. test as more appropriate. Taking this into account the Refugee Board concluded

66 The cassation complaint (skarga kasacyjna) of the Refugee Board against the Warsaw Administrative Court judgement of 22 September 2015 in case IV SA/Wa 681/15 (Refugee Board, 7 January 2016) unpublished and on file with the author.

67 Sufi and Elmi (n. 62), para. 294.

68 N. v the UK, App. no. 26565/05 (ECtHR, 27 May 2008), paras 42 and 43.

69 M.S.S., para. 253. 
that the condition of a safe settlement option in a part of a country of origin free from the risk of persecution or serious harm and including the reasonable settlement criterion, in case of the situation in Ukraine should be perceived in the way that unless compelling humanitarian grounds regarding the prevailing circumstances in the safe part of Ukraine or individual circumstances of the person concerned existed and in consequence excluded the settlement option, the IPA might be applied.

The above example was an interesting effort aimed at harmonisation of the case law of the Polish refugee status determination authorities and administrative courts based on the case law of the ECtHR. In this respect it would be a true example of proper judicial dialogue. Yet, the effort appeared to be unsuccessful as the appeal claim was rejected on purely procedural grounds. It is very unfortunate indeed, as the case law of the Polish authorities remains highly diversified within the analysed scope. In another Ukrainian case - which was almost identical to that mentioned above - the Warsaw Administrative Court shared the reasoning of the Refugee Board and dismissed the appeal. It stated, among others, that it

shares the position formulated by the [ECtHR] in the cases referred to by [the Refugee Board] [...] in which it was accepted that States are obliged not to expel foreigners only in situation in which extreme poverty is predicted, when the foreigner concerned is a person wholly dependent on State support and he or she is faced with official indifference of his or her State's authorities which is incompatible with human dignity. It is about the living conditions in the place of relocation that are so bad that the foreigner's existence, his or her life as well as his or her health (understood as the need to safeguard the basic medical care) may be endangered to such a degree that it actually results in a necessity to return the territory where the risk of persecution exists. ${ }^{70}$

However, it should be stressed that in numerous other decisions of the Refugee Board dealing with the IPA principle application and especially in the context of the appropriate standard of the actual accessibility of effective protection, there are no references whatsoever to the case law of the ECtHR. Instead, the numerous references may be identified to the UNHCR guidelines and to the 'reasonableness'

70 "Podziela stanowisko sformułowane przez Europejski Trybunał Praw Człowieka w powołanych przez organ wyrokach [...], w których uznano, iż państwa mają obowiązek powstrzymania się od wydalania cudzoziemców jedynie w sytuacji prognozy skrajnego ubóstwa, gdy cudzoziemiec jest osobą całkowicie zależną od pomocy państwa i znalazł się w obliczu obojętności organów swojego państwa, nie do pogodzenia z godnością człowieka. Chodzi tu o warunki życia w miejscu relokacji na tyle złe, że egzystencja cudzoziemca, jego życie, a także zdrowie (rozumiane jako potrzeba zapewnienia mu podstawowej opieki medycznej) może być na tyle zagrożona, iż realnie skutkuje koniecznością powrotu na teren, na którym istnieje zagrożenie prześladowaniem", case IV SA/Wa 694/15 (Warsaw Administrative Court, 24 September 2015). 
test. According to this test it is required to determine whether in the relocation region the person concerned may lead 'a relatively normal life' without undue hardship. ${ }^{71}$ This is the dominant position adopted by the Refugee Board, which has been also approved in the case law of the administrative courts.

\subsection{Granting Subsidiary Protection and the Denial of Access to Adequate Medical Treatment}

The consideration of the relationship between the subsidiary protection when an applicant is in need of an adequate medical treatment is the subject of another bulk of case law exemplifying the judicial dialogue in the Polish context. In these particular cases if an applicant is denied protection, his suffering is caused by the lack of access to the adequate medical treatment. Another problem that is worth analysing in the context of the judicial dialogue on refugee law is the question of granting international protection to the seriously ill in case their return to the country of origin would cause their suffering due to the lack of access to adequate medical care and the necessary treatment. Of course, in a situation in which the denial of access to adequate medical treatment would be intentional due to one of the reasons enumerated in the refugee definition the person concerned would meet the criteria to be granted refugee status. Such situations are extremely rare though. The situations which are much more frequent are the ones in which a seriously ill foreigner would be deprived of the adequate medical treatment in case of return to his or her country of origin because of poor health system there resulting in no access to particular medical treatment. This is the frequent case of persons with HIV and AIDS-related conditions coming from numerous African States in which the health systems do not guarantee an adequate (or any) treatment.

Yet, the persons concerned could be, as it seems, covered by subsidiary protection under Art. 15(b) of the Qualification Directive, which defines the risk of serious harm consisting of torture or inhuman or degrading treatment or punishment of an applicant in the country of origin. Thus, this provision directly corresponds with the prohibition of Art. 3 ECHR. According to the ECtHR, in exceptional cases the removal of the ill foreigner to his or her country of origin may constitute a violation of Art. 3 ECHR and, therefore, cannot be executed. For the first time the ECtHR decided so in the famous 1997 judgment $D . v$ the $U K^{72}$ and subsequently established a de facto precedent in the $2008 \mathrm{~N}$. $v$ the UK Grand Chamber judgement where it determined a very high threshold of 'compelling humanitarian grounds' as the only exceptional situation in which the removal is to be excluded. Indeed, this is a very restrictive standard and as such it has

71 See e.g. Refugee Board cases: RdU-956-1/S/15 (22 April 2016); RdU-588-2/S/15 (17 March 2016); RdU-560-2/S/15 (4 December 2015).

72 D. $v$ the UK, App. no. $30240 / 96$ (ECtHR, 2 May 1997). 
been under a harsh critique in the doctrine and by the non-governmental organisations. Also, it is characteristic that the N. standard has been criticised within the ECtHR itself and numerous judges expressed their calls for the liberalisation of the standard in diversified separate opinions annexed the ECtHR judgements. ${ }^{73}$ Nevertheless the $N$. standard remains to be applied by the ECtHR. It should be noted, however, that the standard offers some flexibility in application of the 'compelling humanitarian grounds' standard to the circumstances of a particular case. It is especially so in case of national authorities making the relevant decisions.

In the Polish practice on granting international protection it was exactly the $N$. standard, which formed the reference point in applying Art. 15(2) of Act on granting protection to foreigners, which is an exact equivalent of Art. 15(b) of the 2011 Qualification Directive. In rare cases did the Refugee Board explicitly refer to the ECtHR case law establishing the relevant interpretation of Art. 3 ECHR and granted subsidiary protection to a seriously ill applicant. An illustrative example of such decision is a case of a young female applicant from Sudan who was very seriously ill, including being HIV positive, was an orphan and presumable was a victim of trafficking in human beings. When granting subsidiary protection to the person concerned, the Refugee Board stated that:

in the case exceptional and compelling humanitarian grounds occur, in the light of which the applicant would be denied the very basic medical care in the country of origin and that would result in placing her in danger of suffering of such a degree of mistreatment that it meets the criteria for endangering the applicant for serious harm consisting in inhuman or degrading treatment. ${ }^{74}$

The Refugee Board decision included the explicit references to both the $D$. and the $N$. judgements of the ECtHR.

In December 2014 the question of interpretation of Art. 15(b) of the 2004 Qualification Directive (yet it is relevant for the 2011 recast version as well) was decided by the CJEU in M'Bodj case. The CJEU considered the preliminary questions of the Belgian court and provided an explanation as to the scope of subsidiary protection under Art. 15(b) of the 2004 Qualification limiting in a radical manner

73 Opinion partiellement concordante commune aux Juges Tulkens, Jočienė, Popović, Karakaş, Raimondi et Pinto de Albuqerque, Yoh-Ekale Mwanje v Belgium, App. no. 10486/10 (ECtHR, 20 December 2011); Concurring opinion of Judge Lemmens joined by Judge Nussberger and Dissenting opinion of Judge Power-Forde, S.J. v Belgium, App. no. 70055/10 (ECtHR, 27 February 2014, Chamber), Dissenting opinion of Judge Pinto de Albuqerque, S.J. v Belgium, App. no. 70055/10 (ECtHR, 15 March 2015, Grand Chamber).

74 "W sprawie zachodzą wyjątkowe i nieodparte okoliczności humanitarne, w świetle których wnioskodawczyni byłaby w kraju pochodzenia pozbawiona podstawowej opieki medycznej, co narażałoby ją na cierpienia o takim stopniu dolegliwości, że spełniają one znamiona doznania przez wnioskodawczynię poważnej krzywdy przez narażenie jej na nieludzkie lub poniżające traktowania", case RdU-246-1/S/13 (Refugee Board, 29 August 2013). 
the possibility of granting this form of international protection to the seriously ill. The CJEU referred directly to the judgement of the ECtHR in the $N$. case and to the standard established there. ${ }^{75}$ Against these pronouncements, it stated that

none the less, the fact that a third country national suffering from a serious illness may not, under Article 3 ECHR as interpreted by the [ECtHR], in highly exceptional cases, be removed to a country in which appropriate treatment is not available does not mean that that person should be granted leave to reside in a Member State by way of subsidiary protection under Directive 2004/83. In the light of the foregoing, Article 15(b) of Directive 2004/83 must be interpreted as meaning that serious harm, as defined by the directive, does not cover a situation in which inhuman or degrading treatment, such as that referred to by the legislation at issue in the main proceedings, to which an applicant suffering from a serious illness may be subjected if returned to his country of origin, is the result of the fact that appropriate treatment is not available in that country, unless such an applicant is intentionally deprived of health care. ${ }^{76}$

What is more, the CJEU explicitly stated that the Member States are not entitled to introduce or to retain more favourable standards in this respect because "it would be contrary to the general scheme and objectives of Directive 2004/83 to grant refugee status and subsidiary protection status to third country nationals in situations which have no connection with the rationale of international protection." ${ }^{77}$

Consequently, the $M^{\prime} B o d j$ judgement, in fact, excluded granting subsidiary protection to the seriously ill foreigners, save the situations in which they would be intentionally deprived of health care. Such restriction will also apply to those who must not be removed due to the guarantees under Art. 3 ECHR. Such restrictive interpretation of torture, inhuman or degrading treatment under Art. 15(b) of the Qualification Directive vis-à-vis the ECtHR interpretation of Art. 3 ECHR seems to be arbitral and thus doubtful. One has to remember however, that at the very same day as the M'Bodj judgement was delivered the CJEU delivered another judgement in case of Abdida ${ }^{78}$ in which it confirmed other guarantees under EU law for the persons concerned on the basis of the Return Directive. Thus, the CJEU reasoning on the Return Directive, as described vividly by Steve Peers described, "transforms an instrument of repression into (in some cases) an instrument for protection." ${ }^{.79}$ The line of the CJEU argumentation perceived jointly in both cases

$75 \operatorname{M'Bodj}$ (n. 48), para. 39.

76 Ibidem, paras 40-41.

77 Ibidem, para. 44.

78 Case C-562/13 Centre public d'action sociale d'Ottignies-Louvain-la-Neuve v Moussa Abdida (CJEU, 18 December 2014).

79 S. Peers, 'Could EU law save Paddington Bear? The CJEU develops a new type of protection' (EU Law Analysis, 21 December 2014), <http://eulawanalysis.blogspot.co.uk> (access: 30 April 2016). 
may be assessed as surprising and deserves a separate analysis exceeding the scope of the present text.

The CJEU position has been rapidly taken into account and referred to in the Polish practice. This may be labelled as the rapid appropriation of the outcome of the European judicial dialogue to the domestic level. The Warsaw Administrative Court judgement of 22 January $2015^{80}$ (so delivered slightly over one month after the M'Bodj and Abdida judgements) is especially worth attention. The Court referred to both of the judgements directly. It started rather surprisingly with references to the Abdida judgement, which were completely irrelevant for the case and subsequently referred to paragraphs 39-41 of the M'Bodj judgement and stated that it precluded granting subsidiary protection to the claimant concerned. The position of the CJEU with direct references to paragraphs 40-41 of the M'Bodj judgement is also included in the decisions of the Refugee Board refusing to grant subsidiary protection unless an applicant is intentionally deprived of health care. ${ }^{81}$ Thus, the question of granting the persons concerned other forms of protection will be decided in separate return procedure. However, those to whom the protection was granted (they could be granted the humanitarian stay permit or tolerated stay permit under the 2013 Act on foreigners ${ }^{82}$ ) will enjoy a significantly less favourable status - especially, but not exclusively, as social conditions are concerned - vis-à-vis those enjoying subsidiary protection.

Undoubtedly, the question under analysis will continue to be the subject of the European judicial dialogue. It has been already heralded by the dissenting opinion of the ECtHR Judge Paulo Pinto de Albuquerque annexed to the S.J. judgement of 2015, in which he criticised sharply the CJEU judgements in M'Bodj and Abdi$d a$ and concluded that "the messy state of the European case law, with its flagrant internal contradictions, makes it even more urgent to review the standard set out in $N$. in the light of international refugee law and international migration law." ${ }^{83}$

\section{Conclusion}

The Polish contribution to judicial dialogue on refugee law is rather modest and definitely could be more elaborate. It especially involves the almost non-existing cross-citations and references to the case law of foreign national courts. At the same time, the potential to exchange arguments in this way in order to reach common understandings of refugee law concepts and mechanisms is high

80 Case IV SA/Wa 2152/14 (Warsaw Administrative Court, 22 January 2015).

81 See e.g. Refugee Board cases: RdU-1109-1/S/15 (7 April 2016); RdU-550-3/S/14 (22 April 2016).

82 Journal of Laws 2013, item 1650, as amended.

83 Dissenting opinion of Judge Pinto de Albuquerque, S.J. (2015), para. 5. 
and should not be neglected. Also, beyond judicial dialogue understood as cross-citation, informal ways of courts' interaction should not be underestimated, as they may be very influential. For obvious reasons they are very difficult to trace.

Due to the Europeanization of the refugee law the references in the Polish case law to the decisions of both the ECtHR and the CJEU are more frequent and to some extent remain mandatory. In this regard the growing importance of the CJEU case law is of highest significance. However, its influence may be perceived - at least to some extent - as controversial as was demonstrated in the analysed example of the M'Bodj case. This is also an illustrative example of the influence of the European courts' judicial dialogue on national case law.

Finally, one more aspect deserves to be brought up. The analysis conducted also shows that the references to both foreign national courts' and international courts' case laws are more frequent and in principle more detailed in the case law of the Refugee Board than in the case law of the administrative courts. It may be claimed that it is so because the Refugee Board is the specialised body dedicated to adjudicate refugee law cases only, whereas the administrative courts are not specialised in this respect and act within general judicial review of public administration. One may claim that this might be an additional argument for the need of reshaping the Polish national institutional framework and for establishing a specialised court or tribunal for refugees or - more broadly - for the law on foreigners' matters. 


\section{Bibliography}

\section{Case law}

\section{ECtHR}

Chahal v the UK, App. no. 22414/93 (15 November 1996)

D. $v$ the UK, App. no. 30240/96 (2 May 1997)

Soering $v$ the UK, App. no. 14038/88 (7 July 1989)

F. $v$ the UK, App. no. 17341/03 (inadmissibility decision, 22 June 2004)

I.I.N. $v$ the Netherlands, App. no. 2035/04 (inadmissibility decision, 9 December 2004)

Salah Sheekh $v$ the Netherlands, App. no. 1948/04 (11 January 2007)

N. $v$ the UK, App. no. 26565/05 (27 May 2008)

T.I. $v$ the UK, App. no. 43844/98 (inadmissibility decision, 7 March 2000)

Yoh-Ekale Mwanje v Belgium, App. no. 10486/10 (20 December 2011)

Tarakhel v Switzerland, App. no. 29217/12 (4 November 2012)

Mamilov v Poland, App. no. 18358/07 (inadmissibility decision/striking out of the list of cases, 20 October 2010)

Sufi and Elmi $v$ the UK, App. nos 8319/07 and 11449/07 (28 June 2011)

M.S.S. $v$ Belgium and Greece, App. no. 30696/09 (21 January 2012)

K.A.B. $v$ Sweden, App. no. 886/11 (5 September 2013)

S.J. v Belgium, App. no. 70055/10 (Chamber, 27 February 2014)

M.E. $v$ Sweden, App. no. 713398/12 (Chamber, 26 June 2014)

S.J. v Belgium, App. no. 70055/10 (Grand Chamber, 15 March 2015)

M.E. $v$ Sweden, App. no. 713398/12 (Grand Chamber, 8 April 2015)

R.H. $v$ Sweden, App. no. 4601/14 (10 September 2015)

\section{CJEU}

C-465/07 Meki Elgafaji, Noor Elgafaji v Staatssecretaris van Justitie (17 February 2009)

C-199/12-C-201/127, X, Y and Z v Minister voor Immigratie en Asiel (7 November 2013)

C-148/13-C-150/13, A, B, C v Staatssecretaris van Veiligheid en Justitie (2 December 2014)

C-542/13 Mohamed M'Bodj v État belge (18 December 2014)

C-562/13 Centre public d'action sociale d'Ottignies-Louvain-la-Neuve v Moussa Abdida (18 December 2014)

C-472/13 Andre Lawrence Shepherd v Bundesrepublik Deutschland (26 February 2015)

\section{Supreme Administrative Court}

V SA 1494/02 (29 January 2003)

II OSK 237/07 (8 May 2008)

\section{Warsaw Administrative Court}

V SA/Wa 874/10 (4 December 2009) 
IV SA/Wa 1387/13 (15 October 2013)

IV SA/Wa 1557/14 (29 October 2014)

IV SA/Wa 2152/14 (22 January 2015)

IV SA/Wa 681/15 (22 September 2015)

IV SA/Wa 694/15 (24 September 2015)

\section{Refugee Board}

RdU-129-4/S/07 (3 April 2009)

RdU-908-1/S/09 (23 October 2009)

RdU-1182-1/S/09 (14 January 2010)

RdU-161-1/S/12 (28 May 2012)

RdU-178-1/S/12 (25 July 2012)

RdU-246-1/S/13 (29 August 2013)

RdU-72-5/S/08 (14 October 2013)

RdU-93-1/S/14 (29 May 2014)

RdU-560-2/S/15 (4 December 2015)

RdU-588-2/S/15 (17 March 2016)

RdU-1109-1/S/15 (7 April 2016)

RdU-956-1/S/15 (22 April 2016)

RdU-550-3/S/14 (22 April 2016)

RdU-705-2/S/15 (27 April 2016)

\section{Other}

Islam $v$ Secretary of State for the Home department; R. V. Immigration Appeal Tribunal, ex p. Shah (1999) 2 AC 629 (HL)

The UK Court of Appeal (Civil Division) in Omoruyi v Secretary of State for the Home Department, (2001) Imm AR 175

Aguirre Cervantes v INS of 21 March 2001 accessed via (2001) 13 International Journal of Refugee Law 586

E. M. v Ministry of Interior 4 Azs 99/2007-93 (Supreme Administrative Court of the Czech Republic - Nejvy̌šsi správní soud, 24 January 2008)

Refugee Appeal No. 76456 (New Zealand: Refugee Status Appeals Authority, 15 March 2010)

HJ (Iran) and HT (Cameroon) v Secretary of State for the Home Department, UKSC 31 (7 July 2010)

\section{References}

\section{Books}

Joly D., Heaven or Hell?: Asylum Policies and Refugees in Europe (Macmillan Press 1996)

Goodwin-Gill G.S., McAdam J., The Refugee in International Law (3 ${ }^{\text {rd }}$ ed., Oxford University Press 2007) 


\section{Book Sections}

Kowalski M., 'Sexuelle Orientierung im Flüchtlingsrecht und im allgemeinen Migrationsrecht Polens unter besonderer Berücksichtigung der Verifizierungsproblematik im Verfahren', [in:] Classen C.D., Richter D., Łukańko B. (eds), 'Sexuelle Orientierung' als Diskriminierungsgrund. Regelungsbedarf in Deutschland und Polen? (Mohr Siebeck 2016) 316

Kowalski M., 'Konflikt na Ukrainie a praktyka udzielania ochrony cudzoziemcom na terytorium Rzeczpospolitej Polskiej' [Ukrainian Conflict and the Practice of Granting Protection to Foreigners on the Territory of the Republic of Poland], [in:] Pudzianowska D. (ed.), Status cudzoziemca $w$ Polsce $w$ świetle wspótczesnych wyzwań międzynarodowych [The Foreigner's Status in Poland in Light of the Contemporary International Challenges] (Wolters Kluwer 2016) 96

Tzanakopoulos A., 'Judicial Dialogue as Means of Interpretation', [in:] Aust H., Nolte G. (eds), The Interpretation of International Law by Domestic Courts: Uniformity, Diversity, Convergence (Oxford University Press 2016) 72

\section{Journal Articles}

Einarsen T., 'The European Convention on Human Rights and the Notion of an Implied Right to de facto Asylum' (1990) 2 International Journal of Refugee Law 361

Benvenisti E., 'Reclaiming Democracy: The Strategic Uses of Foreign and International Law by National Courts' (2008) 102 American Journal of International Law 241

Lambert H., 'Transnational Judicial Dialogue, Harmonization and the Common European Asylum System' (2009) 58 International and Comparative Law Quarterly 519

Weßels J., 'HJ (Iran) and HT (Cameroon) - Reflections on a new test for sexuality-based asylum claims in Britain' (2012) 24 International Journal of Refugee Law 815

Frishman O., 'Transnational Judicial Dialogue as an Organisation Field' (2013) 19 European Law Journal 739

Bank R., 'The Potential and Limitations of the Court of Justice of the European Union in Shaping International Refugee Law' (2015) 27 International Journal of Refugee Law 213

\section{Other}

Aldenhoff L., Clayton G., McDonough P., Actors of Protection and the Application of the Internal Protection Alternative. European Comparative Report (European Council on Refugees and Exiles 2014)

Cafaggi F. et al., Judicial Interactions Techniques - Their Potential and Use in European Fundamental Rights Adjudication (European University Institute 2014)

Peers S., 'Could EU law save Paddington Bear? The CJEU develops a new type of protection' (EU Law Analysis, 21 December 2014), <http://eulawanalysis.blogspot.co.uk> (access: 30 April 2016)

UNHCR, Guidelines on International Protection No 4: "Internal Flight or Relocation Alternative" within the Context of Article 1A(2) of the 1951 Convention and/or 1967 Protocol Relating to the Status of Refugees, HCR/GIP/03/04, 23 July 2003

UNHCR, Handbook on Procedures and Criteria for Determining Refugee Status under the 1951 Convention and the 1967 Protocol relating to the Status of Refugees (Geneva 1992, reedited) 